\title{
Stem anatomy and development of interxylary phloem in Strychnos bredemeyeri (Loganiaceae)
}

Roger Moya ${ }^{1}$, Amit Dhanjinbhai Gondaliya ${ }^{2}$ \& Kishore Shankarsinh Rajput ${ }^{2}$

1 Escuela de Ingeniería Forestal, Instituto Tecnológico de Costa Rica, Cartago, Costa Rica.

2 Department of Botany, Faculty of Science, The Maharaja Sayajirao University of Baroda, Vadodara 390002 , India.

\section{Correspondence}

KS. Rajput

E-mail: ks.rajput15@yahoo.com

Received: 13 January 2016

Accepted: 26 April 2017

Published on-line: 11 May 2017

\section{Resumen}

Anatomía del tallo y desarrollo del floema interxilar en Strychnos bredemeyeri (Loganiaceae)

En Strychnos bredemeyeri, pequeñas porciones de cambium dejan temporalmente de producir xilema secundario y produce más floema centrífugamente. Un nuevo segmento del cambium se diferencia en la parte exterior de este floema formado, entonces estos se unen al cilindro regular para formar un anillo. Esta repetida actividad da como resultado la inclusión de islas de floema dentro del xilema secundario, Ilamado floema interxilar. Luego aparecen nuevos elementos del floema asociado al cambium y a las islas de floema que aplastan los elementos no conductores de islas de floema. Junto al floema interxilar, el floema intraxilar está formado por la adición desde las células marginales de la médula. Posteriormente, pequeños arcos del cambium interno se inician en el borde interno del protoxilema en tallos gruesos.

Palabras clave: Variante en el cambium, Floema incluso, Floema interxilar, Liana, Floema intraxilar, Xilema secundario, Floema secundario.

\begin{abstract}
In Strychnos bredemeyeri small segments of the cambium cease to produce secondary xylem temporarily and produce more phloem centrifugally. A new segment of the cambium differentiates outside to this phloem, which unite with the regular cylinder to form a complete ring by leaving the cambium segment in the furrow. Such repeated activity of cambium results in inclusion of phloem islands within the secondary xylem, called interxylary phloem. New phloem elements added by the cambium associated with phloem islands crush the non-conducting sieve elements in older phloem islands. Beside interxylary phloem, intraxylary phloem is added from the marginal pith cells. Subsequently, small arcs of the internal cambium initiate on the inner margin of the protoxylem in thick stems.
\end{abstract}

Key words: Cambial variant, Included phloem, Interxylary phloem, Liana, Intraxylary phloem, Secondary xylem, Secondary phloem. 


\section{Introduction}

Climbing plants differ from self-supporting ones in their growth pattern. In plants with a self-supporting growth form, most of their energy is diverted towards radial growth for the mechanical support of the crown biomass. Non-self-supporting species (mainly vines climbers, twinners, lianas etc.) rely on external structure for the mechanical support (Schnitzer \& Bongers 2011, Wyka et al. 2013, Angyalossy et al. 2015) and they utilize their photosynthate in extension growth to compete for above ground resources (Bowling \& Vaughn 2009, Schnitzer \& Bongers 2011). During this shift from self-supporting to climbing habit, some of them have modified their mechanical architecture such as presence of successive cambia, inter- and intraxylary phloem, vessel dimorphism, vascular tracheids, abundant parenchyma and multi-seriate and tall rays (Speck \& Bugert 2011, Rajput et al. 2010, 2013). Among these features, occurrence of interxylary phloem is restricted to 15 families while 10 examples from different families of dicotyledon are recoded as doubtful by Carlquist (2013), and recommended for further study on them.

Interxylary or included phloem is considered as foraminate type only when the phloem strands are embedded within thick walled xylem (Mikesell \& Popham 1976). Interxylary phloem are composed of strands of isolated or group of sieve tube elements and companion cells along with axial parenchyma embedded within the secondary xylem (IAWA Committee 1989, van Veenendaal \& den Outer 1993, Rajput et al. 2009, Carlquist 2002, 2013). Interxylary phloem strands vary in sizes and they may anastomose to form a three-dimensional structure that inter-connects each other. According to Carlquist $(2001,2013)$ application of the term "interxylary phloem" is misnomer in case of plants with successive cambia and in real sense it should be used to the condition where a single cambium (regular) forms phloem internally. Further he grouped interxylary phloem into five subtypes on the basis of its topography such as: small strands composed of one or two sieve elements (e.g. Stylidium Sw. ex Willd.), phloem strands in extensive parenchyma (e.g. Thunbergia Retz.), in large bands (e.g. Gaura L.), strands in confluent parenchyma (e.g. Combretum Loefl.) and as a large phloem strands (e.g. Strychnos L.). However, ontogenetically it may be clas- sified as:

- Combretum subtype, small segments of cambium produce phloem cells in place of the xylem. After a brief period of such activity, these cambium segments restore their normal function and bury the inwardly formed phloem within the xylem (Eames \& McDaniels 1947, Patil \& Rajput 2008).

- Strychnos subtype, xylem production retards over small arcs of the cambium and the original circular outline of the cambium was restored by complementary segment formed outside to it (Eames \& McDaniels 1947, Philipson 1990, van Veenendaal \& den Outer 1993, den Outer \& van Veenendaal 1995, Rajput et al. 2010).

- Azima subtype, cambial initials differentiate into xylem parenchyma, subsequently these parenchyma dedifferentiate into cells that resume meristematic activity, and finally a redifferentiation into strands of phloem (den Outer \& van Veenendaal 1981).

- Calycopteris subtype, cells in the middle of the cambial zone in small segments differentiate into their derivatives, thus splitting the cambial zone into outer and inner segments. The outer segment restore cambial cylinder by joining with existing cambial ring while the inner one became encircled by differentiating xylem (Rajput et al. 2009).

Scott \& Brebner (1889) and Solereder (1908) described interxylary phloem in Strychnos (selfsupporting member) more than a century ago. Subsequently, several reports appeared on the occurrence of included phloem in several species of Strychnos (Chalk \& Chattaway 1937, Cockrell 1941, Duvigneaud et al. 1952, Obaton 1960, Leeuwenberg 1969, Metcalfe 1983, van Veenendaal \& den Outer 1993, Araque et al. 2000). Structure of secondary xylem of several climbing species of Strychnos including Strychnos bredemeyeri (Schult.) Sprague \& Sandwith $(=S$. pedunculata (A. DC.) Benth.) is described by Cockrell (1941). In all the species of Strychnos, pattern of interxylary phloem development remains similar; therefore, the opinion on its origin is almost undisputed. In the present study, we describe structural variations in the secondary xylem and the development of inter- and intraxylary phloem in the liana $S$. bredemeyeri (Loganiaceae). We also analyse any correlations between habit and anatomy in the transfer from the erect to the climbing habit, and compare our results with those from the literature. 


\section{Material and methods}

Samples of various diameters $(5-20 \mathrm{~mm})$ were collected from the main stem and young branches of $S$. bredemeyeri growing at Banejos de Sierpe, Península de Osa, Costa Rica. Samples were collected twice i.e. in last week of February and second week of March 2016 and every time three individuals were sampled. Samples were cut into 40-60 $\mathrm{mm}$ long pieces and immediately fixed in FAA (Berlyn \& Miksche 1976). They were aspirated and transferred to $70 \%$ alcohol after $24 \mathrm{hrs}$ of fixation in FAA for further processing and storage.

Stem pieces of different diameter were cut into standard anatomical sections of $15-20 \mu \mathrm{m}$ thick with the help of sliding microtome (American Optics Corp. Model No. 860). Sections were double stained with safranin 'O'-fast green FCF (Johansen 1940) and safranin-Astrablue combination (Srebotnik \& Messener 1994) and they were mounted in Canada balsam.

Micro-photographs were taken with the help of Cannon DC 150 Digital Camera attached to a Leica DM 2000 (Germany) research microscope.

Small pieces of xylem adjacent to the cambium were macerated with Jeffrey's solution (Berlyn \& Miksche 1976) at 55 to $60^{\circ} \mathrm{C}$ for $24-36$ hrs and stained with $0.5 \%$ aqueous safranin. Thirty measurements for each cell type were measured randomly to obtain the mean and standard deviation. Wood descriptions follow the IAWA Committee (1989).

\section{Results}

Stems of S. bredemeyeri are circular in outline and showed formation of inter- and intraxylary phloem. Difference is also observed in the structure of secondary xylem that formed prior to- and after the development of climbing habit. Therefore, for the sake of convenience, we first describe the ontogeny of vascular elements followed by detailed anatomy of secondary vascular tissues separately.

\section{Development of the young stem}

Increase in stem thickness of $S$. bredemeyeri is by a single vascular cambium. In the young stem, epidermis forms outermost layer, which is made up of oval to circular cells that are covered with thick cuticle (Fig. 1A). The epidermis is followed by cortex that is composed of oval to polygonal parenchyma cells with isolated or group of 2-3 perivascular sclereids are distributed randomly (Fig. 1A). In $5-7 \mathrm{~mm}$ thick stems, the epidermis is replaced by several cell layered (periderm) cork cells (Fig. 1B). As the stem thickness increases, continuous and tangential band of sclereids differentiate from the cortical parenchyma cells (Fig. 1B). At this stage, the cortical parenchyma cells became tangentially flattened in response to increase in the stem diameter (Fig. 1B). Pericycle and endodermis is indistinct while the outer cortical cells differentiate into continuous tangential bands of sclereids (Fig. 1B). In thick stems, epidermis is replaced by several cells wide periderm that is composed of radially arranged cells.

On the inner side of the pericycle, fascicular region of several collateral vascular bundles are joined by a segment of interfascicular cambium to complete the cylinder of the vascular cambium. This single ring of cambium remains functional throughout the lifespan of the S. bredemeyeri. The pith is composed of thin walled and more or less isodiametric parenchymatous cells. Intraxylary (perimedullar) protophloem strands are present in the peripheral part of the pith (Fig. 1C). In transverse view, it appears as oval to circular pockets that are separated from each other by narrow band of radially elongated cells (Fig. 1C). It is composed of sieve elements, companion cells and axial parenchyma.

\section{Development of interxylary phloem}

Development of interxylary (included) phloem starts after the formation of 3-5 $\mathrm{mm}$ of secondary xylem i.e. after shifting from self-supporting to lianescent stage in the young stems. Initially the cambium is functionally normal and forms secondary xylem centripetally and secondary phloem centrifugally (Fig. 1B). Subsequently, inward development of secondary xylem became temporarily very slow (almost undetectable) ceases in the small segments of the cambium and produce more phloem centrifugally while the rest of the cambium continues to divide bidirectionally (Fig. 1D). Therefore, the segment of cambium that temporarily cease to produce xylem becomes disconnected form rest of the cambium and results in the formation of wedge due to normal functioning of adjacent cambial segments (Fig. 1D, E). Formation of furrows disconnects these small segments from 

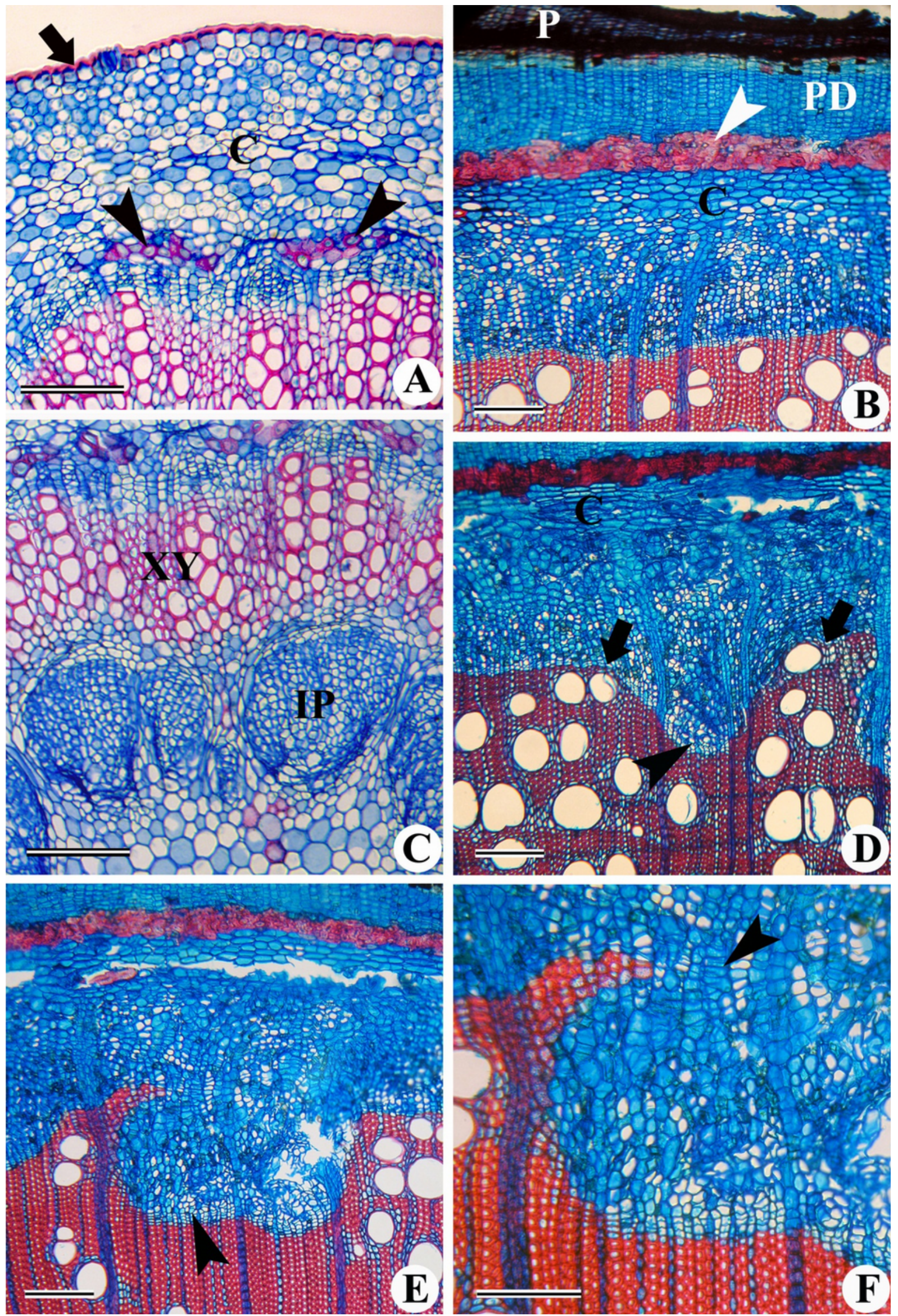
Figura 1. Corte transversal de tallos jóven y maduro de Strychnos bredemeyeri mostrando varios estados de desarrollo. A: Tallo joven mostrando la epidermis, cutítula (flecha), córtex (C), floema y xilema. Las puntas de flecha señalan esclereidas perivasculares aisladas. Nótese que la endodermis y el periciclo son indistintos. B: Tallo relativamente delgado mostrando el súber (P), felodermo (PD) y el córtex, con células alargadas tangencialmente. Nótese la banda continua de esclereidas (punta de flecha) debajo del felodermo. C: Porción de médula de $10 \mathrm{~mm}$ de tallo delgado mostrando el floema intexilar (IP) y elementos del xilema (XY). D: Segmento del cambium que se detuvo para formar xilema secundario (punta de flecha) mientras que otra porción del cambium muestra la producción normal de xilema (flechas). Nótese las células corticales del parénquima (C) tangencialmente aplanadas. E: Cuña formada en respuesta al incremento de la producción de floema e interrupción producción de xilema en pequeños segmentos del cambium (punta de flecha). F: Comienzo del segmento del cambium (punta de flecha). Barras de escala: A, C, F=250 $\mu \mathrm{m} ; \mathrm{B}, \mathrm{D}, \mathrm{E}=500 \mu \mathrm{m}$.

Figure 1. Transverse view of young and mature stems of Strychnos bredemeyeri showing various stages of development. A: Young stem showing epidermis, cuticle (arrow), cortex (C), phloem and xylem. Arrowheads indicate isolated perivascular sclereids. Note that endodermis and pericycle are indistinct. B: A relatively thick stem showing phellem (P), pelloderm (PD) and cortex with tangentially elongate cells (C). Note the continuous band of sclereids (arrowhead) below the phelloderm. C: Pith portion of 10 mm thick stem showing intraxylary phloem (IP) and xylem elements (XY). D: Segment of the cambium that ceased to form secondary xylem (arrowhead) while other portion of the cambium shows production of xylem normally (arrows). Note the tangentially flattened cortical parenchyma cells (C). E: Wedge formed in response to increased phloem production and cessation of xylem production in small segments of cambium (arrowhead). F: Initiation of cambial segment (arrowhead). Scale bar: A, C, F=250 $\mu \mathrm{m} ; \mathrm{B}, \mathrm{D}, \mathrm{E}=500 \mu \mathrm{m}$.

the rest of cambial ring. A new segment of cambium differentiates from the phloem parenchymatous cells (Figs. 1F, 2A) and interconnects the detached ends of the cambium to form a complete cylinder. Production of secondary xylem internally and secondary phloem externally from these segments encloses the sunken segments of the cambium (Fig. 2B) and results in the formation of an isolated strand, appears as an "island" in cross section. As the secondary growth progress further, several interxylary phloem islands are formed in similar fashion as described above (Fig 2C). The cambial segments embedded along with phloem island remain active by forming secondary phloem externally. In thick stems, numerous unevenly organised strands of interxylary phloem having different shapes and dimensions in cross section thus become embedded in thick-walled lignified xylem elements (Fig. 2C).

\section{Structure of secondary xylem}

Structure of secondary xylem differs in self-supporting and climbing (lianescent) stage. In both the stages, secondary xylem was diffuse porous with indistinct growth rings (Fig. 3A). It was composed of tracheids, vessels, fibres with bordered pits (i.e. fibre tracheid), axial and ray parenchyma cells (Fig. 3B. C). Tracheids are relatively wider than the fibres tracheids with alternate bordered pits while fibre tracheids are relatively longer and narrow in diameters with tapered ends. Young stems and shoots growing straight and just started climbing showed significant difference in the structure and composition of secondary xylem (Fig. 3A-D). Therefore, we describe the anatomy of secondary vascular tissues separately as:
Juvenile wood: At the juvenile (self-supporting) stage, secondary xylem is composed of vessels, fibre tracheids, axial and ray parenchyma cells. Vessels mostly solitary, tangential diameter narrow (Fig. 3A) with simple perforation plate on slightly oblique end walls while radial multiples are rare. Their frequency ranges from 27-37 $(32 \pm 1.35)$ per $\mathrm{mm}^{2}$. Vessel elements are 445-525 (485 \pm 8.04$) \mu \mathrm{m}$ in length and 49-90 (70 \pm 2.80$) \mu \mathrm{m}$ in tangential diameter. Fibres thick-walled with narrow lumen and arranged in radial files with bordered pits are common on both radial and tangential walls; 858-992 $(925 \pm 12.84) \mu \mathrm{m}$ long, and 13-17 (14.9 \pm 1.48$) \mu \mathrm{m}$ wide. Rays heterocellular, composed of upright cells and exclusively uni- to biseriate ray cells (Fig. 3B). At this stage the axial parenchyma cells are scanty paratracheal to unilateral paratracheal type (Fig. 3A).

Mature (lianescent) xylem: As the plants shift to lianescent stage, structure of secondary xylem alters significantly (Figs. 3C, D). Vessels are mostly solitary but radial or diagonal multiples are also observed occasionally. Their frequency and tangential diameter increases significantly while their length decreases as compared to juvenile wood (Figs. 2A, 3C, Table 1). Vessel elements possess simple perforation plate on transverse to slightly oblique end walls. Their frequency ranges from 47-52 $(49 \pm 0.63)$ vessels per $\mathrm{mm}^{2}$. Rays mostly two to several cells wide while uniseriate rays are rare and observed intermixed with them (Fig. 3D). They are hetero-cellular with oval to polygonal, small and large ray cells intermixed with vertically upright cells (Fig. 3D).

They are $346-435(372 \pm 8.33) \mu \mathrm{m}$ in height and 27-63 (48 \pm 2.13$) \mu \mathrm{m}$ in width. Fibre tracheids formed after the lianescent stage are longer as 
compared to the self-supporting stage (Table 1) and possess distinct bordered pits. The bordered pits are oval to oblong or circular in outline,

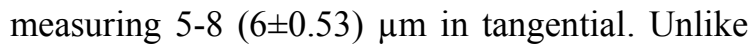
self-supporting stage, number of axial parenchyma increased in lianescent stage and is unilateral paratracheal type (Fig. 3C).

\section{Structure of regular (external) phloem}

Thick stem shows presence of interxylary phloem and external regular phloem (Fig. 4A). An external phloem is composed of sieve elements, companion cells, axial and ray parenchyma cells. The sieve tube elements are 357-466 (413 \pm 8.44$)$ $\mu \mathrm{m}$ in length and 19-26 $(24 \pm 1.21) \mu \mathrm{m}$ in tangen-
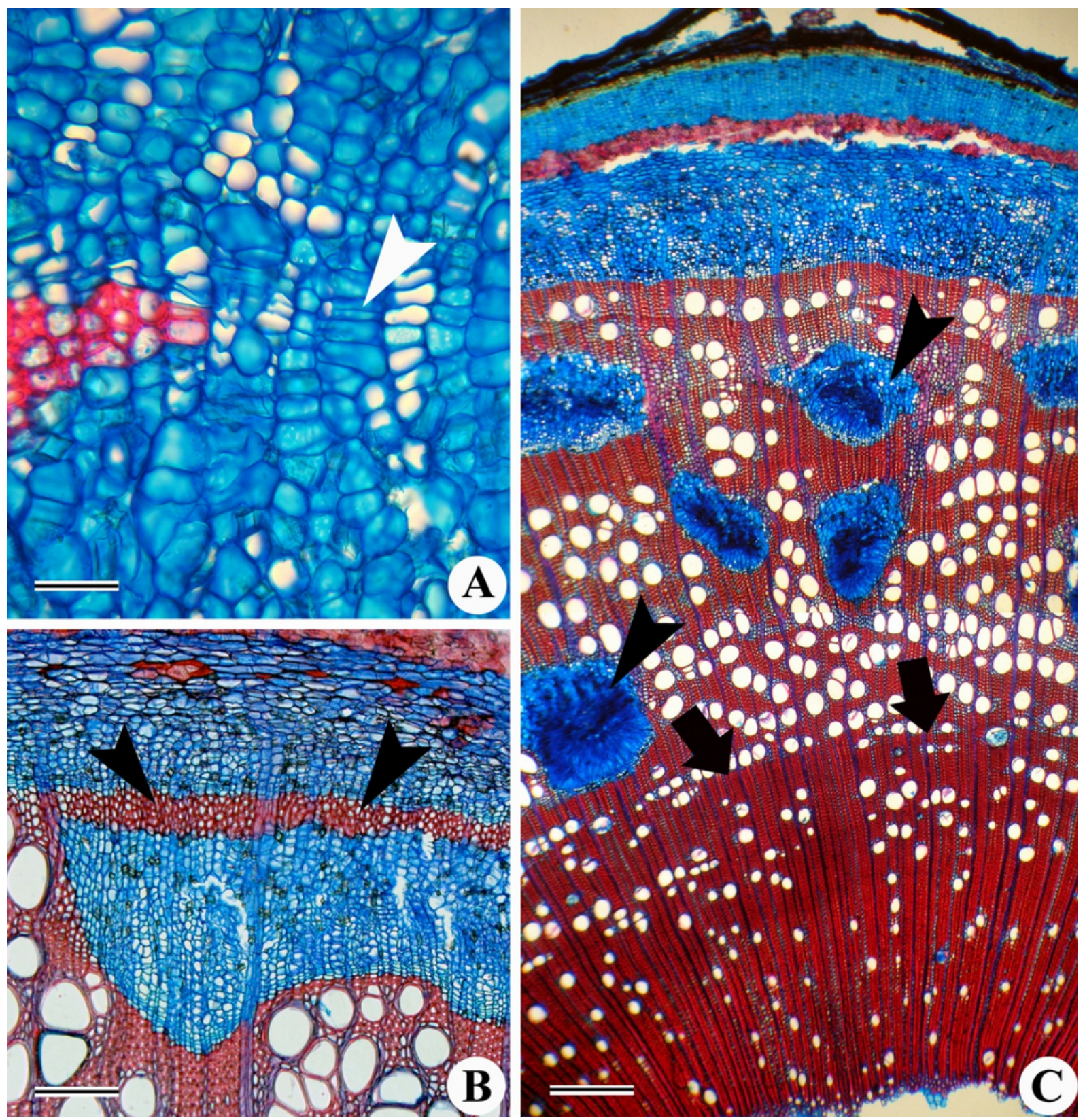

Figura 2. Corte transversal de tallo de Strychnos bredemeyeri mostrando el inicio del cambium nuevo, desarrollo de sus derivados y estructura del xilema secundario. A: Ampliación de la figura 1Fmostrando el inicio del los nuevos segmentos del cambium. La punta de flecha señala las divisiones tangenciales en las células parenquimatosas. B: La diferenciación del xilema (puntas de flecha), desde el recién iniciado cambium, envuelve al floema dentro del xilema secundario. C: Estructura del xilema secundario mostrando las islas de floema (puntas de flecha) embebidas en el xilema. Nótese la variación estructural en el xilema formado anterior y posteriormente al hábitat trepador. barras de escala: $\mathrm{A}=100 \mu \mathrm{m}, \mathrm{B}=250 \mu \mathrm{m} ; \mathrm{C}=500 \mu \mathrm{m}$.

Figure 2. Transverse view of Strychnos bredemeyeri stem showing initiation of new cambium, development of its derivatives and structure of secondary xylem. A: Enlarged view of figure $1 \mathrm{~F}$ showing initiation of new cambial segments. Arrowhead indicates tangential divisions in the parenchyma cells. B: Differentiation of xylem (arrowheads) from the newly initiated cambium encloses the phloem within secondary xylem. C: Structure of secondary xylem showing phloem islands (arrowheads) embedded within xylem. Note the structural variation in xylem formed prior to and after climbing habit. Scale bar: $A=100 \mu \mathrm{m}, \mathrm{B}=250 \mu \mathrm{m} ; \mathrm{C}=500 \mu \mathrm{m}$. 

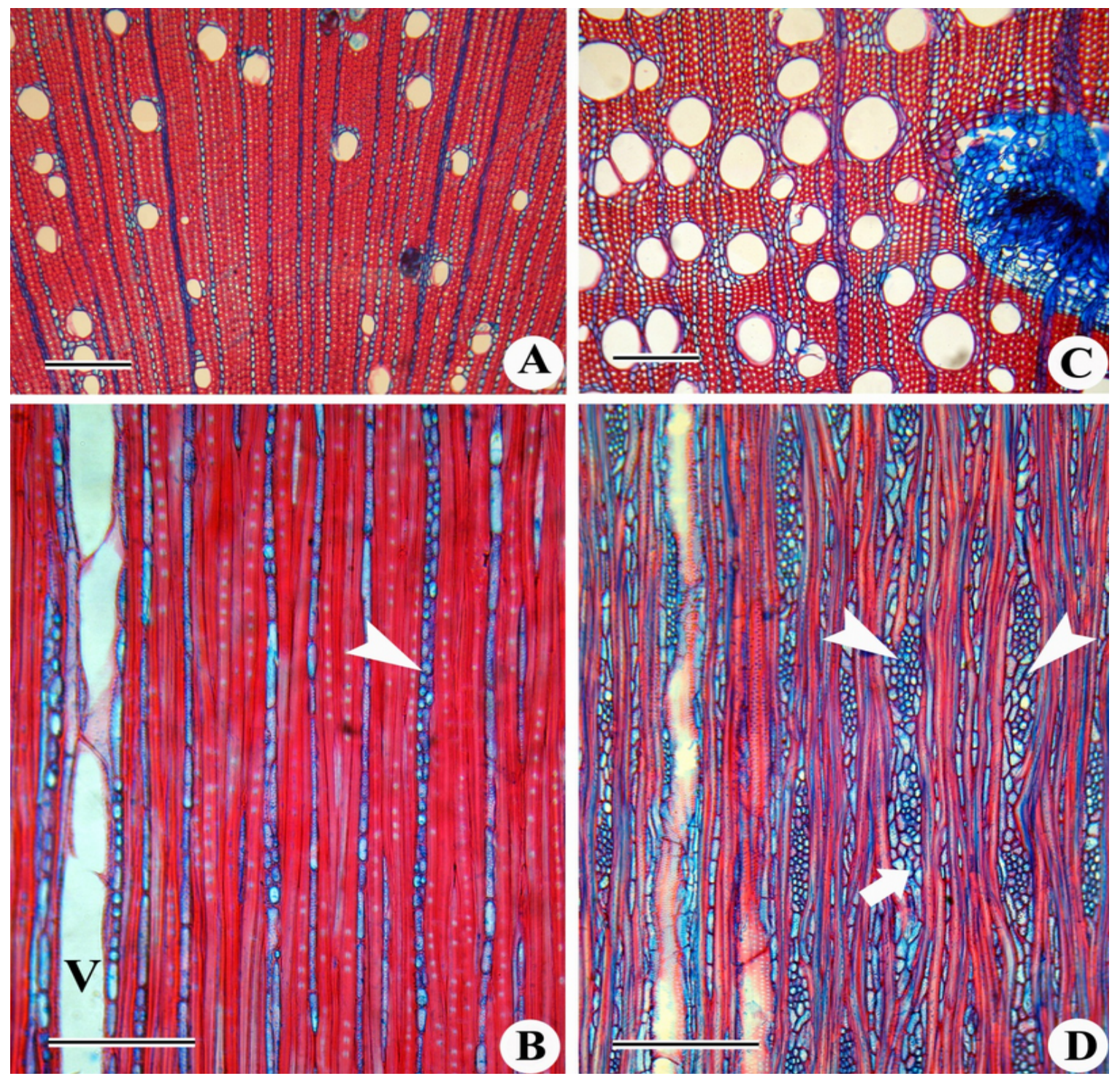

Figura 3. Cortes transversales $(A, C)$ y longitudinales $(B, D)$ de xilema secundario auto-sustentante $(A, B)$ respecto a xilema lianescente $(C$, D) de Strychnos bredemeyeri. A: Estructura del xilema en la etapa auto-sustentante. Nótese que el número de vasos y la distribución del parénquima. B: Estructura del xilema secundario en la etapa auto-sustentante. Las puntas de flecha señalan los haces uni-biseriados. Nótese los huecos bordeados de las paredes laterales de las fibrotraqueidas. V=vaso. C: Estructura del xilema en la etapa trepadora. Nótese el el número de vasos y la distribucion del parénquima. D: Xilema secundario formado en la etapa trepadora. Nótese la estructura de los haces (puntas de flecha) y las células parenquimáticas marginales (flecha). Barras de escala: $\mathrm{A}, \mathrm{C}=750 \mu \mathrm{m}, \mathrm{B}=250 \mu \mathrm{m} ; \mathrm{B}, \mathrm{D}=500 \mu \mathrm{m}$.

Figure 3. Transvers (A, C) and tangential longitudinal (B, D) view of self-supporting secondary xylem (A, B) vs. lianescent xylem (C, D) of Strychnos bredemeyeri. A: Structure of xylem at self-supporting stage. Note the number of vessels and parenchyma distribution. B: Structure of secondary xylem at self-supporting stage. Arrowhead indicates uni-biseriate rays. Note the bordered pits on lateral walls of fibre tracheids. $\mathrm{V}=$ vessel. C: Structure of xylem at climbing stage. Note the number of vessels and parenchyma distribution. D: Secondary xylem formed at climbing stage. Note the structure of rays (arrowheads) and marginal ray cells (arrow). Scale bar: A, C=750 $\mu \mathrm{m}, \mathrm{B}=250 \mu \mathrm{m} ; \mathrm{B}, \mathrm{D}=500 \mu \mathrm{m}$.

\begin{tabular}{|l|l|c|c|}
\multicolumn{4}{|c}{} \\
\multirow{2}{*}{ Wide vessel element } & Length & Juvenile secondary xylem & Mature (lianescent) xylem \\
\cline { 2 - 4 } & Diameter & $445-525(485 \pm 8.04)$ & $376-455(415 \pm 12.41)$ \\
\hline \multirow{2}{*}{ Narrow/ fibriform vessel element } & Length & $327-574(70 \pm 3.80)$ & $98-149(124 \pm 9.72)$ \\
\cline { 2 - 4 } & Diameter & $40-99(72 \pm 2.80)$ & $376--455(415 \pm 12.41)$ \\
\hline \multirow{2}{*}{ Fibre tracheids } & Length & $858-992(925 \pm 12.84)$ & $98-149(124 \pm 9.72)$ \\
\cline { 2 - 4 } & Width & $13-17(14.9 \pm 1.48)$ & $1089-1197(1143 \pm 17.04)$ \\
\hline \multirow{2}{*}{ Ray } & Height & $139-505(349 \pm 19.50)$ & $267-653(409 \pm 0.97)$ \\
\cline { 2 - 4 } & Width & $10-18(13.59 \pm 0.54)$ & $25-45(32.80 \pm 1.07)$ \\
\hline Vessel frequency per $\mathrm{mm}^{2}$ & & $27-37(32 \pm 1.35)$ & $47-52(49 \pm 0.63)$ \\
\hline
\end{tabular}

Tabla 1. Dimensiones del xilema secundario (vasos, fibrotraqueidas y parénquima) Strychnos bredemeyeri. Los valores entre paréntesis representan la media y la desviación estándar.

Table 1. Dimensional details of secondary xylem (vessel elements, fibre tracheids, and rays) Strychnos bredemeyeri. Values in parentheses represent mean and standard deviation. 

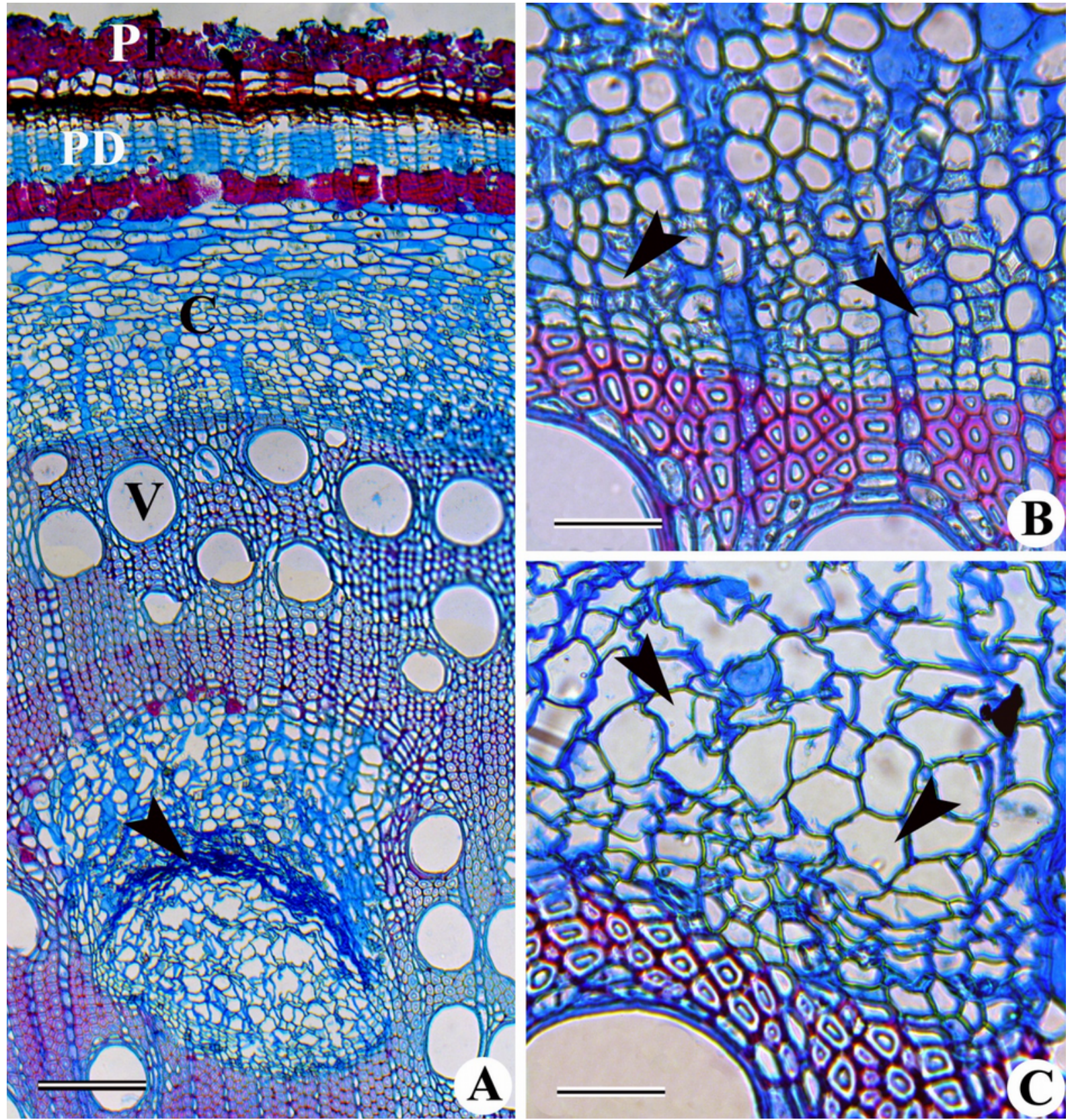

Figura 4. Estructura de las islas del floema en tallo de Strychnos bredemeyeri. A: Parte de tallo grueso mostrando el floema aplastado (punta de flecha) en una isla de floema de formación anterior. $\mathrm{P}=$ felema, $\mathrm{PD}=$ filas radiales de célumas felodérmicas; $\mathrm{C}=$ córtex; $\mathrm{V}=$ vaso. B: Estructura del floema externo normal. Nótese el diámetro de los tubos cribosos (puntas de flecha) y el número de elementos cribosos. C: Vista amplada de la figura 4A, mostrando una isla interxilar de floema.. Nótese el diámetro de los tubos cribosos (puntas de flecha). Barras de escala: $\mathrm{A}=500 \mu \mathrm{m} ; \mathrm{B}$ and $\mathrm{C}=50 \mu \mathrm{m}$.

Figure 4. Structure of phloem islands in Strychnos bredemeyeri stem. A: Part of the thick stem showing crushed phloem (arrowheads) in earlier formed phloem island. $\mathrm{P}=$ phellem; $\mathrm{PD}=$ radial rows of phelloderm cells; $\mathrm{C}=$ cortex, $\mathrm{V}=$ vessel. $\mathbf{B}$ : Structure of normal external phloem. Note the diameter of the sieve tubes (arrowheads) and the number of sieve elements. C: Enlarged view of figure 4A showing an interxylary phloem island. Note the diameter of the sieve tubes (arrowheads). Scale bar: $\mathrm{A}=500 \mu \mathrm{m} ; \mathrm{B}$ and $\mathrm{C}=50 \mu \mathrm{m}$

\begin{tabular}{|l|c|c|c|}
\hline $\begin{array}{c}\text { Sieve } \\
\text { element }\end{array}$ & $\begin{array}{c}\text { External mature phloem } \\
\text { sieve element }\end{array}$ & $\begin{array}{c}\text { Interxylary phloem } \\
\text { sieve element }\end{array}$ & $\begin{array}{c}\text { Intraxylary phloem } \\
\text { sieve element }\end{array}$ \\
\hline Length & $357-466(413 \pm 8.44)$ & $426-514(468 \pm 9.69)$ & $327-386(359 \pm 19.26)$ \\
\hline Diameter & $19-26(24 \pm 1.21)$ & $32-37(35 \pm 1.82)$ & $35-40(39 \pm 2.28)$ \\
\hline
\end{tabular}

Tabla 2. Dimensiones de los tubos cribosos del floema regula (externo), interxilar e intraxilar de Strychnos bredemeyeri. Los valores entre paréntesis representan la media y la desviación estándar.

Table 2. Dimensional details sieve tube elements from regular (external), interxylary and intraxylary phloem of Strychnos bredemeyeri. Values in parentheses represent mean and standard deviation. 

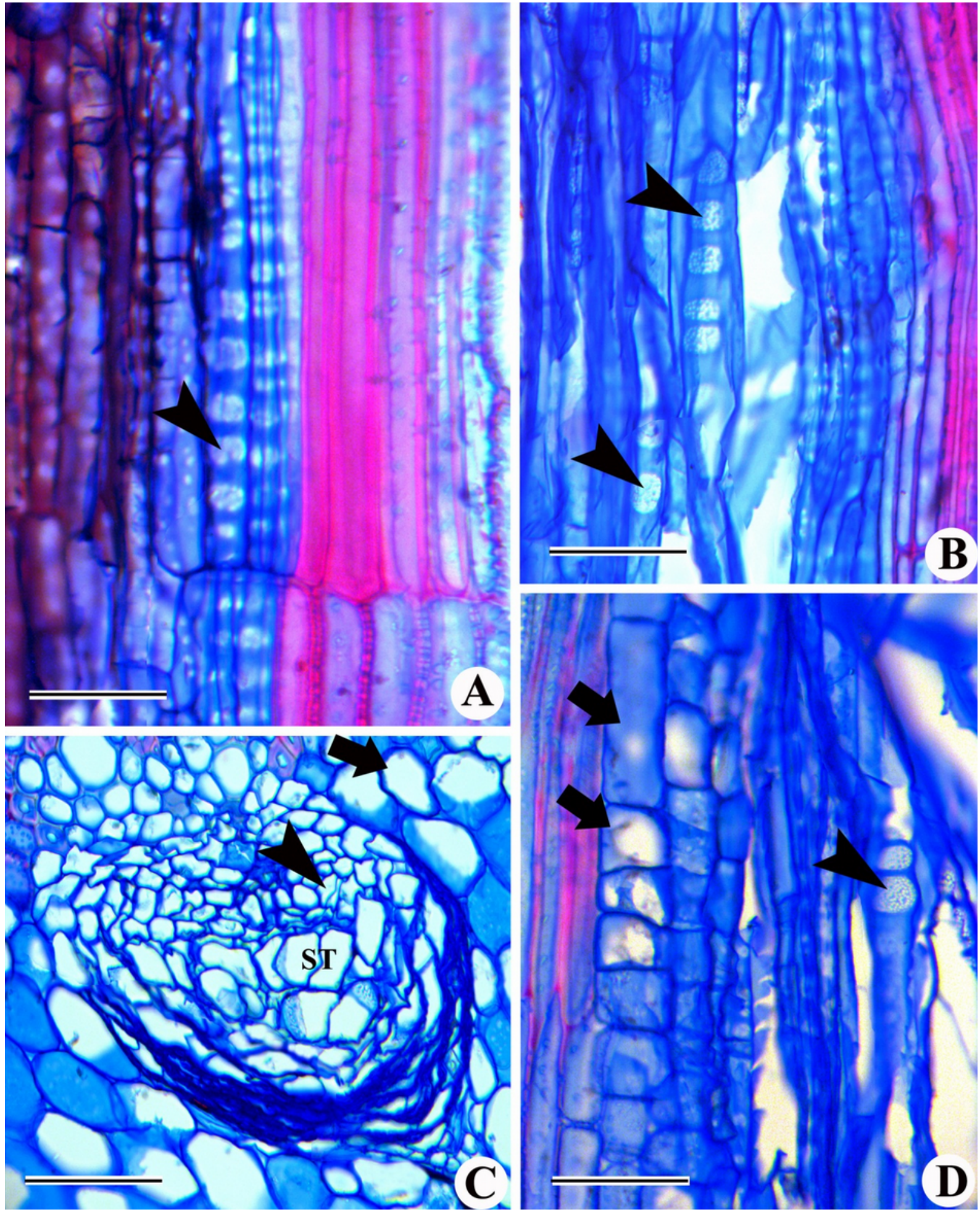

Figura 5. Secciones radial (A, B, D) y tranversal (C) de tallo de Strychnos bredemeyeri mostrando el floema externo, inter e intraxilar. A: Floema externo mostrando elementos de conducción con áreas cribosas laterlaes (puntas de flechas) bien desarrolladas. B: Elementos de conducción interxilares mostrando áreas cribosas (puntas de flechas) en las paredes laterales. Nótese la variación en las áreas cribosas de las figuras 5A y 5B. C: Floema interxilar mostrando tubos cribosos (ST) y células que dan lugar a el floema intraxilar (punta de flecha). Nótese la variación de tamaño de las células medulares (flecha). D: Porción de la médula mostrando la placa cribosa compuesta (punta de flecha). Barras de escala: : A-D $=50 \mu \mathrm{m}$.

Figure 5. Radial (A, B, D) and transverse (C) section of Strychnos bredemeyeri stem showing external, inter-and intraxylary phloem. A: External phloem showing sieve elements with well developed lateral sieve areas (arrowhead). B: Interxylary sieve element showing sieve areas (arrowheads) on lateral walls. Note the variation in laterals sieve areas between figures 5A and B. C: Intraxylary phloem showing large sieve tube (ST) and cells that give rise to intraxylary phloem (arrowhead). Note the cell size variation in adjacent pith cells (arrow). D: Portion of the pith showing compound sieve plate (arrowhead). Scale bar: A-D=50 $\mu \mathrm{m}$. 
tial diameter. Each sieve element is associated with a companion cell and possessed compound sieve plate with well-developed lateral sieve areas (Fig. 4B). They are mostly oval to circular in outline but rectangular sieve elements with small diameter are also observed. They are solitary or arranged in pair and intermixed with axial parenchyma cells. Visually, sieve elements are relatively infrequent and scattered within axial parenchyma cells. In this phloem, axial parenchyma cells are more abundant as compared to sieve elements (Fig. 4B). Axial parenchyma also showed presence of rhomboidal crystals. Phloem rays unitriseriate, heterocellular with oval to polygonal small and large ray cells that are intermixed with upright cells.

\section{Structure of interxylary phloem}

Interxylary phloem islands are composed of sieve elements, companion cells, axial and ray parenchyma cells (Figs. 4C, 5C). A portion of the rays traversing the phloem islands are uni-triseriate, thin walled while they are thick walled in the lignified portion of the secondary xylem. Sieve elements possess compound sieve plate with welldeveloped sieve areas on lateral walls (Fig. 5B). Length of the sieve elements is more as compared to external and intraxylary phloem while their diameter is less in comparison to intraxylary phloem (Table 2). Each island is oval to oblong or tangentially wide and may be small or of considerably large in size (Figs. 2C, 4A). As the stem thickness increase, the earlier formed islands get embedded inside the thick walled xylem derivatives, whereas sieve elements in earlier formed islands showed heavy accumulation of callose. Subsequently, they became non-conducting and undergo obliteration in earlier formed phloem islands. The obliterated phloem appears as a cap on the outer border of each phloem islands of the thick stems while on the outer part of the same stem they are in the middle of each island (Fig. 4A). However, these non-conducting sieve elements are replaced by newly added sieve elements from the cambial arcs that are present on the inner margin of each phloem islands.

As compared to regular external phloem (Fig. 4B), interxylary sieve tube elements are wider (Fig. 4C) and longer (Table 2). Unlike regular phloem, sieve elements are more abundant in the phloem islands while axial parenchyma cells are relatively less. These axial parenchyma cells also showed presence of rhomboidal crystals.

\section{Structure of intraxylary phloem}

The intraxylary phloem is composed of sieve elements, companion cells, axial parenchyma cells while adjacent strands of phloem are separated by radially elongated parenchyma cells (Fig. 1C). As compared to regular and interxylary phloem sieve tube elements are shorter while they are wider than other two types (Table 2). They possess obliquely oriented compound sieve plates on the end walls (Fig. 5C, D) while lateral walls show several poorly developed sieve areas (Fig. 5D). Compared to external normal phloem they are more in length and width (Table 1). As the secondary growth progress further, additional sieve elements are added by parenchymatous cells located on the inner margin of protoxylem (Fig. 5C). Morphologically, these cells differ from the adjacent pith cells in having relatively less diameter while pith cells are several times wider (Fig. 5C). Moreover, these cells act as reservoir for the continuous production of intraxylary phloem while origin of internal cambium was not observed even in 10-12 $\mathrm{mm}$ thick stems. New sieve elements are added from the marginal cells; therefore, earlier formed sieve elements become non-conductive and undergo obliteration and form a cap like structure toward centre of the pith (Fig. 5C).

\section{Discussion}

Strands of sieve tubes and associated parenchyma cells that are embedded within the secondary xylem of the stem and roots are referred as interxylary phloem or included phloem (IAWA Committee 1989). However, this definition broadly includes the phloem formed by successive cambia as well as by a single ring of cambium. Therefore, Carlquist $(2001,2013)$ disagree with IAWA committee (1989) definition and he restricted the term to those cases where phloem is embedded within secondary xylem of stem and root that has single ring of cambium. Further, he suggested that the term interxylary phloem should not be used in case of plants with successive cambia because the phloem in this instance lies between secondary and conjunctive tissues. Interxylary phloem is composed of sieve tube elements, companion cells, ray and axial parenchyma. Occurrence of interxylary phloem has been restricted to small fraction of dicotyledonous taxa including herbs, 
shrubs, trees and lianas. Usually such plants possess a single ring of vascular cambium (Carlquist 2013). Occurrence and development of interxylary phloem in different species of Strychnos (including trees and lianas) is well known and thoroughly studied by earlier workers (Scott \& Brebner 1889, Solereder 1908, Chalk \& Chattaway 1937, Cockrell 1941, Duvigneaud et al. 1952, Obaton 1960, Leeuwenberg 1969, Metcalfe 1983, van Veenendaal \& den Outer 1993, Araque et al. 2000, Rajput et al. 2010). Development of interxylary phloem in $S$. bredemeyeri fits into Strychnos subtype as described by earlier researchers (Eames \& McDaniels 1947, Metcalfe 1983, van Veenendaal \& den Outer 1993) and there is no ambiguity about its origin from a single cambium.

In the present study, development of interxylary phloem is observed only after the initiation of climbing habit. No much information is available on the onset of interxylary phloem development and it may change on the basis of age of the plants. Carlquist (2013) shows some of the examples in which development interxylary phloem is absent in the earlier formed secondary xylem while in Dobera Juss. and Salvadora Schweick., it begins early and remains constant. Further, he cited the study of Mennega (1980) stating that interxylary phloem was absent in some species of Strychnos and other members of Loganiaceae in which only small diameter stems were available for the study while stems with larger diameter showed presence of interxylary phloem. However, further studies are warranted to study the time of interxylary phloem development and initiation of climbing habit.

Structure of secondary xylem in climbing species differs significantly from the self-supporting (erect) species to facilitate stem flexibility and protection of the stem from torsion, bending and internal injury (Fischer \& Ewers 1989, Rowe \& Speck 1996, Carlquist 2001, Speck \& Bugert 2011) in response to external factors or swinging of the stems (Rajput 2015). Secondary xylem of self-supporting shoots and saplings of $S$. bredemeyeri showed narrow lumen fibres with thick walls, narrow vessels with uniseriate rays and scanty paratracheal parenchyma comparable to other self-supporting plants. Samples collected from with climbing habit showed considerable variations in the structure of secondary xylem. It is characterized by presence of wider vessels with higher frequency while rays become two to several cells wide. Compared to self-supporting stage, number of axial parenchyma increased and changed from scanty paratracheal to unilateral paratracheal type.

Occurrence of wider vessels with rays as compared to self-supporting stage and increased number of axial parenchyma is characteristic to climbing habit (Ellmore \& Ewers 1985, Fisher \& Ewers 1989, Ewers et al. 1991, Rowe \& Speck 1996, Carlquist 2001, Rajput et al. 2013). Ewers et al. (2015) correlated, increase in vessel diameter and their frequency with the leaf surface area and amount of water required for transpiration while decreased mechanical tissue helps to increase stem flexibility by decreasing the stem stiffness. All these features provide stem flexibility for twisting around the host without any disadvantageous effect on conductivity of the secondary xylem (Rowe \& Speck 2005, Angyalossy et al. 2011). Though, wider vessels have higher efficiency of water conduction (Angyalossy et al. 2011) but they are considered to be extremely susceptible to air embolism (Ellmore \& Ewers 1985, Ewers et al. 1991, Rowe \& Speck 1996, Carlquist 2001, Rajput et al. 2013). Experimental studies carried out on Tynanthus cognatus Miers. (Bignoniaceae) by Angyalossy et al. (2011) showed that the vessels formed in the centre of the stem remain functional while those located on the periphery of the stem were embolised. Presence of both wider and narrow vessels intermixed with other elements of secondary xylem in $S$. bredemeyeri before and after the development of climbing habit may be providing conductive safety.

Occurrence of thick walled xylem fibres and bi- to multiseriate rays is characteristic to Strychnos (Cockrell 1941). In the present study, we also observed thick walled xylem fibres with bordered pits and with uni-biseriate rays in self-supporting stage while they become bi- to multiseriate as the plants develop climbing habit, which is ascribed as characteristic of climbing habit (Ewers et al. 1991, Rowe \& Speck 1996, Carlquist 2001). Presence of scanty paratracheal to aliform confluent axial parenchyma has been reported in different species of Strychnos. In the present study $S$. bredemeyeri also showed variation in the distribution of axial parenchyma during self-supporting and lianescent stage. Increased axial parenchyma and ray width is correlated with the increasing the 
stem flexibility to cope up with climbing habit (Fischer \& Ewers 1989, Ewers et al. 1991, Rowe \& Speck 1996). In the present study, parenchyma distribution changes from scanty paratracheal to unilateral paratracheal type.

Though there are several studies on the formation of interxylary phloem in various dicotyledon species (Scott \& Brebner 1889; Solereder 1908; Chalk \& Chattaway 1937; Cockrell 1941; Duvigneaud et al. 1952, Obaton 1960, Leeuwenberg 1969, den Outer \& van Veenedaal 1981, Metcalfe 1983, van Veenendaal \& den Outer 1993, Rajput et al. 2009, 2010) but there is no much comparative information on the dimensional details of sieve elements formed externally and at interxylary position by a cambial ring. van Veenendaal $\&$ den Outer (1993) documented similar variation in the length and width of the external and interxylary sieve tube elements of Strychnos millepunctata Leeuwenb. In the present study also external sieve elements are shorter in length and diameter of the sieve elements is less as compared to included phloem. Our results are in agreement with van Veenendaal \& den Outer (1993) that interxylary sieve tube elements are longer and more in diameter. Similar feature has also been reported in several members of the Bignoniaceae by Pace et al. (2011) and in Dolichandra unguiscati (L.) L.G. Lohmann by Dobbins (1971). Lens et al. (2008) reported sieve elements with much wide diameter in Phytocrene sp. (pp. 537, Fig. 4C-E) of Icacinaceae. Similarly longer sieve elements with more lumen diameter of both, sieve elements and phloem parenchyma have been reported in Strychnos biocolor Prog. by Rajput et al. (2010).

Relatively little information is available on the distribution of sieve elements in normal external and variant phloem (Carlquist 2013, Pace et al. 2011, 2015). In the present study, S. bredemeyeri showed relatively less number of sieve elements and more axial parenchyma. In contrast, inter- and intraxylary phloem possessed more sieve elements while axial parenchyma cells are relatively less. Pace et al. (2011) also reported similar variation in the distribution pattern of sieve elements between normal and variant secondary phloem in several members of Bignoniaceae. Similar variations may be also seen figure 4C-E shown by Lens et al. (2008) in Phytocrene sp. Therefore, we presume that major part of photosynthate transport is performed inter- and intraxylary phloem while external phloem may be acting as a subsidiary pathway. Various functions such as: photosynthate transport, its storage, rapid and large volume transport in plants showing massive flowering or large fruits and for providing additional pathways for photosynthate transport by earlier workers (Carlquist 2013). Experimental studies are needed to confirm the actual function of interxylary phloem (Gondaliya \& Rajput 2016).

In conclusion, $S$. bredemeyeri follows a similar pattern of interxylary phloem development as described for other species of Strychnos by earlier workers. Length of the sieve elemnts in variant (inter- and intraxylary) is more as compared to normal external phloem. Number of sieve elements is sparse in the external (normal) phloem while parenchyma cells are more. In contrast, inter- and intraxylary phloem is mostly composed of sieve elements while parenchyma cells are less. Variation in the distribution of sieve elements in external and variant phloem indicates that variant phloem may be playing important role in translocation of photosynthate. Further studies are warranted to confirm the role of variant phloem by using recent tools.

\section{Acknowledgement}

One of the authors (KSR) is thankful to The M.S. University of Baroda, Vadodara for travel support, SERB, Government of India and to Vicerrectoría de Investigación de la Escuela de Ingeniería Forestal, Instituto Tecnológico de Costa Rica for financial support for local hospitality and to carryout fieldwork. Authors are also thankful to Reinaldo Aguilar for the identification of specimens. Authors are thankful to Dr. Juan Jose Presa and both the anonymous reviewers for their valuable suggestions on the previous version of the manuscript.

\section{References}

Angyalossy V, Angeles G, Pace MR, Lima AC, DiasLeme CL, Lúcia G, Lohmann LG \& Carolina MaderoVega C. 2011. An overview on the anatomy, development and evolution of the vascular system of lianas. Plant Ecology \& Diversity 5(2): 167--182.

Angyalossy V, Pace MR \& Lima AC. 2015. Liana anatomy: a broad perspective on structural evolution of the vascular system. In: Schnitzer SA, Bongers F, Burnham RJ \& Putz FE (Eds) Ecology of lianas. John Wiley \& Sons, West Sussex, UK. pp 254-287.

Araque OZ, de Pernia NE \& León WJ. 2000. Estudio 
anatómico del leño de seis especies de lianas. Revista Forestal Venezolana 44(2): 39-48

Berlyn GP \& Miksche JP. 1976. Botanical Microtechnique and Cytochemistry. Ames, lowa: The lowa State University Press, $326 \mathrm{pp}$.

Bowling AJ \& Vaughn KC. 2009. Gelatinous fibres are widespread in coiling tendrils and twining vines. American Journal of Botany 96(4): 719-727.

Carlquist S. 2001. Comparative wood anatomy: Systematic, ecological and evolutionary aspect of dicotyledon wood. Springer, Berlin, Heidelberg, New York.

Carlquist S. 2013. Interxylary phloem: Diversity and functions. Brittonia 65: 477-495.

Chalk L \& Chattaway MM. 1937. Identification of woods with included phloem. Tropical Woods 50: 1-31.

Cockrell RA. 1941. A comparative study of the wood structure of several South American species of Strychnos. American Journal of Botany 28(1): 32-41.

den Outer RW \& van Veenendaal WLH. 1981. Wood and bark anatomy of Azima tetracantha Lam. (Salvadoraceae) with description of its included phloem. Acta Botanica Neerlandica 30: 199-207.

Duvigneaud P, Staquet J \& Dewit J. 1952. Contribution a I' etude anatomique des rameaux chez les sections africaines du genre Strychnos. Bulletin de la Société Royale de Botanique de Belgique 85: 39-67.

Eames A \& McDaniels LH. 1947. An introduction to plant anatomy, Tata McGraw-Hill Publication Co. Ltd. pp. 311.

Ellmore GS \& Ewers FW. 1985. Hydraulic conductivity in trunk xylem of elm, Ulmus Americana. International Association of Wood Anatomists Journal 6: 303-307.

Ewers FW, Fisher JB \& Fitchner K. 1991. Water flux and xylem structure in vines. In Putz FE \& Mooney HA. (eds.) Biology of vines. Cambridge University Press, Cambridge. 127-160 pp.

Ewers FW, Rosell JA \& Olson ME. 2015. Liana as structural parasites. In: Hacke U (ed) Functional and ecological xylem anatomy. Springer International Publishing Switzerland. 163-188 pp.

Fischer JB \& Ewers FW. 1989. Wound healing in stems of lianas after twisting and girdling injury. Botanical Gazette 150: 251-265.

Gondaliya AD \& Rajput KS. 2016. Stem anatomy and development of inter- and intraxylary phloem in Leptadenia pyrotechnica (Forssk.) Dence. (Asclepiadaceae). Plant Biosystems [1-11] http://dx.doi.org/ 10.1080/11263504.2016.1218968

IAWA Committee. 1989. List of microscopic features for hardwood identification. International Association of Wood Anatomists Bulletin ns 10: 221-332.

Johansen DA. 1940. Plant microtechnique. Mc Graw Hill, New York.

Lens F, Karehed J, Bass P, Jansen S, Rabaey D, Huysmans S, Hamann T. \& Smets E. 2008. The wood anatomy of polyphyletic Icacinaceae s.I. and their relationships within asterids. Taxon 57 (2): 525-552.

Leeuwenberg AJM. 1969. The Loganiaceae of Africa. VIII. Strychnos III. Mededeelingen van de Landbouwhogeschool te Wageningen 69: 1-36.

Metcalfe CR. 1983. Anomalous structure. In Metcalfe C. R. and Chalk L. (eds.) Anatomy of dicotyledons II. pp. 52-63, 210-211. Clarendon Press.

Obaton M. 1960. Les lianes ligneuses a structure anomales des forets denses d'Afrique occidentale. Annales des Sciences Naturelles; Botanique 12: 1220.

Pace M, Lohmann LG \& Angyalossy V. 2011. Evolution of disparity between the regular and variant phloem in Bignonieae (Bignoniaceae). American Journal of Botany 98(4): 602-618.

Philipson WR. 1990. Anomalous cambia. In Iqbal M. (eds.) The vascular cambium. John Wiley and Sons, New York. pp 201-212

Rajput KS. 2015. Comparative study on secondary xylem and formation of successive cambia in stems and roots of Antigonon leptopus Hook. \& Arn. (Polygonaceae). Flora 217: 131-137.

Rajput KS, Patil VS \& Rao KS. 2009. Development of included phloem in Calycopteris floribunda Lamk. (Combretaceae). Journal of Torrey Botanical Society 136: 302-312.

Rajput KS, Fiamengui MB \& Marcati CR. 2010. Stem anatomy of Strychnos bicolor Prog. (Loganiacceae) from Brazilian Cerrado. Phytomorphology 60: 48-56.

Rajput KS, Patil VS \& Rao KS. 2013. Wood anatomy and the development of interxylary phloem of Ipomoea hederifolia Linn. (Convolvulaceae). Journal of Plant Growth Regulation 32: 654-662.

Rao KS \& Rajput KS. 1999. Seasonal behaviour of vascular cambium in teak (Tectona grandis L.f.) growing in moist deciduous and dry deciduous forests. IAWA J. 20: 85-93.

Rowe NP \& Speck T. 1996. Biomechanical characteristics of the ontogeny and growth habit of the tropical liana Candylocarpon guianensis (Apocynaceae). International Journal of Plant Sciences 157(4): 406417.

Rowe NP \& Speck T. 2005. Plant growth forms: An ecological and evolutionary perspective. New Phytologist 166: 61-72.

Rowe N, Isnard S \& Speck T. 2004. Diversity of mechanical architectures in climbing plants: An evolutionary perspective. Journal of Plant Growth Regulation 23: 108-128.

Scott DH \& Brebner G. 1889. On the Anatomy and histogeny of Strychnos. Annals of Botany 3 (3): 275-304

Schnitzer SA \& Bongers F. 2011. Increasing liana abundance and biomass in tropical forest: emerging pattern and putative mechanism. Ecology Letters 14: 397-406.

Solereder H. 1908. Systematische Anatomie der Dicotyledonen: Enke, Stuttgart. pp 405-407.

Speck T \& Bugert I. 2011. Plant Stems: Functional design and mechanics. Annual Review of Material Research 41:169-93.

Srebotnik E \& Messener K. 1994. A simple method that uses differential staining and light microscopy to assess the selectivity of wood delignification by white rot fungi. Applied and Environmental Microbiology 60: 1383-1386.

van Veenendaal WLH \& den Outer RW. 1993. Development of included phloem and organisation of the phloem network in the stem of Strychnos millepunctata (Loganiaceae). International Association of Wood Anatomists Journal 14: 253-365.

Wyka TP, Oleksyn J, Karolewski P \& Schnitzer SA. 2013. Phenotypic correlates of linescent growth form: A review. Annals of Botany 112: 1667-1681. 